\title{
PIDANA PEMILU DAN PILKADA OLEH SENTRA PENEGAKAN HUKUM TERPADU
}

\author{
Muhammad Junaidi \\ Magister Hukum, Universitas Semarang, Semarang \\ institut.junaidi@gmail.com,
}

\begin{abstract}
Abstrak
Penelitian ini menelaah posisi Sentra Gakkumdu (Penegakan Hukum Terpadu) oleh penyelenggara pilkada dalam menyelesaikan tindak pidana pilkada yang menuai banyak masalah dalam menjamin pelaksanaan demokrasi. Mulai dari adanya pola koordinasi yang tidak mungkin dilakukan secara sistemik antara penegak hukum sampai dengan disharmonisasi keputusan-keputusan yang dibuat berkaitan dengan implikasi terjadinya tindak pidana pilkada yang dilakukan secara menyeluruh menjadi masalah pokok dan yang paling utama adalah tumpang tindih kewenangan antar lembaga yang tergabung dalam Gakkumdu. Sesuai kajian yuridis normatif, maka adanya upaya untuk review ulang kapasitas Sentra Gakkumdu sangatlah penting dilakukan, utamanya dengan mempertimbangkan kapasitas filosofis kelembagaan antara lembaga yang ada dalam Sentra Gakkumdu selama ini berangkat belajar dari pelaksanaan pemilu 2019 di Indonesia silam. Temuan dlam penelitian ini adalah agar peran Badan Pengawas pemilu (Bawaslu) harus menjadi lembaga sentral dalam kelembagaan Gakkumdu sehingga nuansa harmonisasi singkronisasi yang tentunya menjadi kelemahan pelaksanaan Pemilu 2019 dapat diminimalisir melalui koordinasi terpusat oleh Bawaslu.
\end{abstract}

Kata Kunci : Pidana; Pilkada dan Pemilu; Penegakan Hukum 


\title{
CRIMINAL ELECTION AND REGIONAL HEAD ELECTION BY INTEGRATED LAW ENFORCEMENT CENTER
}

\author{
Muhammad Junaidi \\ Master of Law, Semarang University, Semarang \\ institut.junaidi@gmail.com,
}

\begin{abstract}
This study aims to examines the position of The Gakkumdu Center (Integrated Law Enforcement) by the regional head election organizers in resolving the crimes of regional head elections that reap many problems in ensuring the implementation of democracy. Starting from a pattern of coordination that is not possible systemically between law enforcement to the disharmonization of decisions made in relation to the implications of the criminal conduct of the Regional Head Election conducted thoroughly becomes a major issue and the main thing is the overlap of authority between institutions incorporated in Gakkumdu. In accordance with normative juridical studies, efforts to review the capacity of The Gakkumdu Center are very important, especially taking into account the institutional philosophical capacity between the institutions in The Gakkumdu Center during this time departing to learn from the implementation of the 2019 Elections in Indonesia ago. The findings of this study are that the role of the Election Supervisory Board (ESB) should be a central institution in the institution of Gakkumdu so that the nuances of synchronizing harmonization that is certainly the weakness of the implementation of election 2019 can be minimized through centralized coordination by ESB.
\end{abstract}

Keywords : Criminal; Regional Head Elections and Elections; Law Enforcement 


\section{PENDAHULUAN}

\section{A. Latar belakang}

Jimly Asshiddiqie menyebutkan bahwa paling tidak ada 11 prinsip pokok yang terkandung dalam negara hukum yang demokrati diantaranya adanya mekanisme penyelesaian sengketa berdasarkan mekanisme aturan yang ditatati bersama itu dam pembatasan kekuasaan melalui mekanisme pemisahan dan pembagian kekuasaan disertai mekanisme penyelesaian sengketa ketatanegaraan antar lembaga negara baik secara vertikal maupun horizontal ${ }^{1}$. Identitas yang demikian merupakan identitas negara hukum yang dapat diterjemahkan menkualifikasikan negara dalam menjalankan kepentingan adalah kepentingan rakyat sebagaimana dijalankan oleh Indonesia. Praktik dalam prinsip negara hukum di atas juga diterapkan pula dalam perlakuan atas tindak pidana pemilu dan pilkada.

Terjadinya penegakan tindak pidana pilkada dalam wujud menjaga marwah dan martabat esensi pemilu dan pilkada sebagai distribusi kekuasaan secara berkemanfaatan menjadi salah satu aspek terpenting dalam menjamin terselenggaranya prinsip negara demokrasi yang dibarengi gagasan Nomokrasi. Menurut Ratna Sholiha ${ }^{2}$ adanya berbagai permasalahan yang kerap muncul dalam penyelenggaraan pemilu di Indonesia menghambat terwujudnya pemilu yang demokratis. Beberapa permasalahan tersebut antara lain, money politics dan black campaign, profesionalitas penyelenggara pemilu, politisasi birokrasi, kualitas dan kapabilitas peserta pemilu atau partai politik, apatisme dan pragmatisme dalam partisipasi politik masyarakat, serta konflik horizontal.

Disinilah pentingnya pengaturan pidana dalam ketentuan pilkada merupakan sebagai bagian dalam menjamin ketertiban. Hal ini menjadi esensi penting pemerintah dalam mengartikan hukum yang oleh pemerintahnya atau pemimpinnya digunakan sebagai sarana dalam merencanakan dan mengorganisasikan struktur

1 Sirajuddin dan Winardi, 2015, Hukum Tata Negara Indonesia, Setara Press(Kelompok Instras Publising), Malang, hlm 282-283

2 Solihah, R., \& Witianti, S. (2017). Permasalahan dan Upaya Mewujudkan Pemilu Demokratis di Indonesia Pasca Reformasill. Jurnal Bawaslu, 3(1). 
ekonomi dan sosial tersebut, dan ia hanya sekadar bagian dan struktur ideologis yang mengontrol realitas materi dan sarana produksi; ia ditentukan dan didefinisikan dalam kaitannya dengan fungsi politisnya. Bahwa seluruh cita hukum berkaitan dengan negara dan karena itu merupakan sarana dengan mana mereka yang mengawasi alat-alat produksi tetap mengawasi mereka yang dicabut hak miliknya. Dengan berpindahnya pemilikan alat-alat produksi ke tangan masyarakat, individu akan dilibatkan, seperti halnya negara dan hukum, yang dibenarkan hanya oleh kebutuhan dengan paksaan ${ }^{3}$. Salah satu wujud dalam mengawal pelaksanaan pemilu dan pilkada adalah dibentuknya Sentra Gakkumdu (Penegakan Hukum Terpadu). Sentra Gakkumdu tentunya diharapkan mampu memberikan nilai-nilai integritas dalam pelaksanaan pemilu dan pilkada yang dilaksanakan.

Penelitian ini juga terkait dengan penelitian Khairul Fahmi (2015) dalam penelitiannya tersebut mengkaji bagaimana hukum pidana atau menggunakan pendekatan pidana, diharapkan berbagai pelanggaran yang dilakukan dapat ditindak dalam rangka memastikan proses pemilu berjalan secara fair. Walaupun demikian, dalam pengaturan dan pelaksanaannya, kemanfaatan hukum pidana dalam penyelenggaraan pemilu belum terasa efektif. Hal itu disebabkan oleh hampir semua subsistem hukum yang menopang bekerja sistem hukum pemilu, yang terdiri dari aturan hukum pidana pemilu, aparat yang terlibat dalam penegakan hukum pemilu dan budaya pihak-pihak yang terlibat dalam penyelenggaaan pemilu. Hasil dari penelitian tersebut juga menyimpulkan bahwa masih perlu banyak perbaikan dimulai dari regulasi, penguatan kapasitas dan profesional penegak hukum dan peningkatan kesadaran stakeholder pemilu guna menciptkan pemilu yang berkualitas. $^{4}$

Terlepas nilai positif peran dari Sentra Gakkumdu (Penegakan Hukum Terpadu) oleh penyelenggara pilkada, terdapat berbagai kelemahan dalam proses dan peran dari Gakkumdu dalam menjalankan tugas dan kewenangannya. Hal

3 Zainal Asikin, 2013, Pengantar Tata Hukum Indonesia, Raja Grafindo Persada, Jakarta, hlm 84

4 Fahmi, Khairul. (2015). Sistem Penanganan Tindak Pidana Pemilu, Jurnal Konstitusi, 12(2), 265-283. http://dx.doi.org/10.31078/jk1224 
tersebut diantaranya adalah problem regulasi yang mensyaratkan bahwa keputusan Gakkumdu haruslah bulat antara Bawaslu, Kejaksaan, dan Kepolisian. Selain itu adanya dissenting opinion (perbedaan pendapat) keputusan Gakkumdu hanya menjadi catatan dalam keputusan, yang disini dapat ditegsakan keputusan masukan bawaslu dapat dikesampingkan oleh Kepolisian atau Kejaksaan. Kondisi masalah regulasi demikian tentunya perlu direspon secara serius sehingga dikemudian hari tidak terjadi masalah dalam pelaksanaan dan peran penegakan pidana pilkada melalui Sentra Gakkumdu sehingga menjadikan pilkada lebih bermartabat.

Pandangan demikian dibenarkan melalui adanya kajian Sukawati Lanang P Perbawa $^{5}$, menyimpulkan bahwa terjadi perbedaan pandangan antara pihak Pengawas Pemilu Kabupaten Badung dengan penyidik. Terkadang pihak panwas merasa perkara sudah layak dijadikan atau ditingkatkan statusnya ke tahap penyidikan, namun penyidik dan jaksa menganggap peristiwa yang terjadi tidak termasuk dalam ranah tindak pidana pemilu.

Penelitian ini melengkapi dari penelitian sebelumnya yang banyak mengkaji tentang penegakan hukum baik di pemilu maupun di pilkada. Perbedaan pemahaman tentang pembuktian antara panwas dengan penyidik maupun penuntut. Kurangnya pemahaman terkait alat bukti yang dibutuhkan didalam melakukan kajian mengakibatkan beberapa tindakan yang diduga merupakan tindak pidana pemilu hanya berakhir di panwaslu, tidak sampai ke kepolisian. Penelitian ini lebih fokus mengkaji evaluasi tentang Sentra Penegakan Hukum Terpadu dalam menanganai pelanggaran pemilu dan pilkada, serta bagaimana penguatan posisi yang ideal bagi Sentara Penagakan Hukum Terpadu dalam menangani pelanggaran pemilu dan pilkada. Penelitian ini bertujuan untuk menelaah posisi Sentra Gakkumdu (Penegakan Hukum Terpadu) oleh penyelenggara pilkada dalam menyelesaikan tindak pidana pilkada yang menui banyak masalah dalam menjamin pelaksanaan demokrasi.

\section{B. Permasalahan}

5 Perbawa, S. L. P. (2019). Penegakan Hukum Dalam Pemilihan Umum, Jurnal Ilmiah Dinamika Sosial, 3(1), 80-102. https://doi.org/10.38043/jids.v3i1.1765 
Berdasarkan analisa kondisi di atas yang utamanya dapat dikaji secara yuridis, maka perlu dilakukan kajian secara komperhensif terkait sejuah mana evaluasi sentra Gakkumdu dalam pengawal pelaksanaan pemilihan umum/pilkada berjalan sebagaimana mestinya. Disamping itu permasalahan lain sejauhmana gagasan terkait penguatan sentra Gakkumdu dalam melaksanakan tugas dan fungsinya juga menjadi bagian terpenting yang akan diuraikan dalam penulisan ini.

\section{Metode Penelitian}

Kajian ini tentunya menarik jika ditelaah dalam perspektif normatif. Hal tersebut berangkat karena judicial independenceis a subject of great interest today, and much of that interesr concern its connectionwith juduicial elections $^{6}$ (independensi peradilan adalah subjek yang sangat diminati saat ini, dan sebagian besar dari minat itu berkaitan dengan hubungannya dengan pemilihan yudisial). Metode pendekatan demikian lebih banyak menggunakan data sekunder yang terdiri dari bahan hukum primer, bahan hukum sekunder dan bahan hokum tertier. Pengumpulan data dilakukan melalui teknis penggalian data kepustakaan. Metode pengumpulan data demikian akan lebih memahamkan kita pada taraf penemuan data lapangan yang telah ditemukan dan terjadi sebelumnya dalam pelaksanaan baik pemilu maupun pilkada yang telah berlangsung. Sedangkan berkaitan dengan analisis dilakukan dengan analisis secara kualitatif. Dalam analisis secara kualitatif, peneliti diharapkan menganalisisnya dengan mengkombinasikan setiap permasalahan yang ada dalam masalah pokok sentra gakumdu yang kemudian dapat menemukan solusi atas permasalahan tersebut dengan mengaitkan tuntutan nilai keadilan yang diharapkan ada dalam lembagalembaga tersebut ${ }^{7}$. Analisis data kualitatif prosesnya berjalan dengan proses mencatat yang menghasilkan catatan lapangan, dengan hal itu diberi kode agar sumber datanya tetap ditelusuri, mengumpulkan, memilah-milah,

\footnotetext{
${ }^{6}$ Baum, L. (2003). Judicial Elections And Judicial Independence: The Voter's Perspective. Ohio St.
} $L J, 64,13$

${ }^{7}$ Lexi J. Moleong, Metodologi Penelitian Kualitatif, Bandung : PT Remaja Rosdakarya, 2018, hlm 23 
mengklasifikasikan, mensintesiskan, membuat ikhtisar dan membuat indeksnya dan kemudian yang terakhir adalah berpikir, dengan jalan membuat agar kategori data itu mempunyai makna, mencari dan menemukan pola dan hubunganhubungan, dan temuan-temuan umum.

\section{PEMBAHASAN}

\section{Evaluasi Sentra Gakkumdu}

Ketidakpahaman dan ketidakmampuan kita dalam menghadopsi kondisi tersebut salah satunya berimplikasi pada kondisi dimana pemilihan kepala daerah atau yang sering kali disebu dengan pilkada sebagai wujud institusionalisasi kedaulatan rakyat menjdi masalah dan atau perkara besar kaena tidak lagi memiliki pemahaman sifat demokratis. Hal tersebut diperparah sistem penangananya pelanggaran pilkada juga tidak maksimal yang salah satunya ditangani oleh Gakkumdu.

Beberapa tindak pidana pilkada maupun pemilu yang dimaksud menjadi kewenangan Sentra Gakkumdu (Penegakan Hukum Terpadu) yang terdapat dalam Undang-Undang Nomor 7 Tahun 2017 Tentang Pemilihan Umum, yang secara garis besar dikelompokan dalam beberapa kualifikasi perbuatan, diantaranya Perbuatan pidana yang ditujukan setiap orang, Perbuatan pidana yang dapat dilakukan oleh petugas KPU, KPU Provinsi, KPU Kabupaten/Kota, PPK, PPS dan PPLN dan Perbuatan pidana yang ditujukan pada pelaksana kampanye.

Dalam pelaksanaan kewenangan tersebut, jika dipahami dalam aspek formal selama ini dalam menjalankan kewenangan, beberapa hal yang dapat dirasakan terkait kelemahan Gakkumdu diantaranya ; pertama, problem regulasi yang mensyaratkan bahwa keputusan Gakkumdu haruslah bulat diantara lembaga yang tergabung dalam sentra Gakkumdu. Kedua, perbedaan pendapat antar lembaga(dissenting opinion) hanya menjadi catatan dalam keputusan. Ketiga, Jaksa dan penyidik termasuk penyidik kepolisian yang tergabung dalam Gakkumdu masih dibebankan tanggung jawab kerja instansi masing-masing sehingga menjadikan tidak berjalan maksimal, dan keempat, Kewenangan Bawaslu yang harusnya punya posisi sentral akan menjadi sejajar dengan lembaga lain (kejaksaan dan kepolisian) yang nyata-nyata independensi secara kelembagaan merupakan 
bagian dari kekuasaan eksekutif yang acapkali pihak-pihak eksekutif sendiri merupakan bagaian kontestan dalam pelaksanaan pilkada dari sumber partai politik. Kelemahan tesebut tentunya menjadi masalah pokok Gakkumdu dalam penangan tindak pidana pilkada ${ }^{8}$. Hal ini juga menjadi masalah dalam praktik integritas pelaksanaan pemilu dan pilkada secara demokratis yang akan dilaksanakan pada masa selanjutnya. Idealnya memang sentra gakkumdu mampu menyelesaikan mengingat peran Sentra Penegakan Hukum Terpadu (Gakkumdu) sebagai sentra penegakan hukum terpadu memiliki peran penting dalam penanganan tindak pidana pilkada, dibentuknya Gakkumdu bermaksud untuk menyamakan pemahaman dan pola penanganan tindak pidana pilkada oleh Bawaslu, Kepolisian Negara Republik Indonesia, dan Kejaksaan Agung Republik Indonesia9 .

Disinilah perlu disadari jika kita melakukan perbandingan di berbagai Negara terkait penanganan pelanggaran pemilu dalam bentuk tindak pidana pemilihan umum dan pilkada. Di negara berkembang bahkan pidana pemilu sangat spesifik. Hal ini berdasarkan hasil penelitian dalm sebuah jurnal dimana Robustness specifications, nonlinear models, and falsification exercises allow us to distinguish among explanations for increased sentencing severity at the end of judges' political cycles. Our findings inform debates over judicial elections, and highlight the interaction between judicial discretion and the influence of judicial elections ${ }^{10}$. Namuan hal ini tidak terjadi di indonesia dimana kurang kesepahaman antar perangkat Sentra Gakkumdu pada saat pembahasan perkara semisal pembahasan sebuah perkara sangat sering terjadi perdebatan yang panjang terkait penerapan unsur-unsur tindak pidana tindak pidana pemilu, apakah perkara tersebut sudah

8 Handitya, B. (2018). Peran Sentra Penegakan Hukum Terpadu (Gakkumdu) dalam Penegakkan Tindak Pidana Pemilu. In Seminar Nasional Hukum Universitas Negeri Semarang (Vol. 4, No. 02, pp. 348-365).

9 Safitri, E. F. (2019). Analisis Peran Sentra Penegakan Hukum Terpadu (Gakkumdu) Dalam Penanggulangan Tindak Pidana Pemilihan Kepala Daerah (Studi Pada Provinsi Lampung).

${ }^{10}$ Berdejó, C., \& Yuchtman, N. (2013). Crime, Punishment, And Politics: An Analysis Of Political Cycles In Criminal Sentencing. Review of Economics and Statistics, 95(3), 741-756. 
memenuhi unsur tindak pidana dan apakah sudah layak di tindak lanjut ketingkat penyidikan oleh Kepolisian ${ }^{11}$.

\section{Penguatan Sentra Gakkumdu}

Upaya penguatan Gakkumdu tentunya tidak dapat dielakkan. Evaluasi Sentra Gakkumdu saat ini tentunya harus dilihat secara objektif dalam kerangka menerapkan sistem penyelengaraan pilkada yang bermartabat. Aspek yang terpenting yang harus diperbaiki adalah sistem penegakan hukum yang jelas dan memiliki filosofi bukan sebagai penegakan tindak pidana umum, akan tetapi sistem penegakan hukum terkait pidana pilkada yang sifatnya harus khusus sebagaimana kekhususan peraturan perundang-undangannya. Hal ini menjadi tantang tersendiri yang perlu dijawab dalam kajian lain tentunya dengan melihat terdapat tantangan dalam tindak pidana pilkada. Faktor perundang-undangan yang kontradiktif antara UU Pemilihan (Les Specialist) dengan aturan limitasi waktu dan KUHP (Lex Generalis) yang dibatasi KUHAP ${ }^{12}$.

Jika kita berangkat dari pemikiran Mahfud yang menyatakan, sejak perubahan tahap ketiga UUD 1945, konstitusi kita sudah mengarahkan agar penegakan hukum di Indonesia secara prinsip menganut secara seimbang segi-segi baik dan konsepsi rechtsstaat dan the rule of law sekaligus yakni menjamin kepastian hukum dan menegakkan keadilan substansial ${ }^{13}$. Ketentuan dalam Peraturan Badan Pengawas Pemilihan Umum Republik Indonesia Nomor 9 Tahun 2018 Tentang Sentra Penegakan Hukum tentunya sangat perlu untuk diselaraskan terlebih pola koordinasi jika kita melakukan evaluasi pada Pelaksanaan Pemilihan Umum tahun 2019. Hal ini menjadi bagian utama dalam menjamin kepastian regulasi. Dalam menjamin kualitas pilkada saat ini Sentra Gakkumdu harus

11 Yeni, Y. (2020). Peran Sentra Penegakan Hukum Terpadu (Gakkumdu) Dalam Penindakan Tindak Pidana Pemilu Pada Pemilihan Anggota Dewan Perwakilan Rakyat Daerah Kabupaten Solok Tahun 2019. Abstract of Undergraduate Research, Faculty of Law, Bung Hatta University, 11(1).

12 Ersan, P., \& Erliyana, A. (2018). Kualifikasi Hukum Pidana Khusus Terhadap Tindak Pidana Pemilu/Pilkada (Tinjauan Hukum Administrasi Negara). Jurnal Pakuan Law Review, 4(1). https://doi.org/10.33751/palar.v4i1

206-207 Ni’matul Huda, 2015, Hukum Tata Negara Indonesia, Raja Grafindo Persada, Jakarta, hlm 
diarahkan mewujudkan filosofis kewenangan Bawaslu secara sentral, maka lembaga lain tentunya dan perlu mengarah pada koordinasi utama yang dilakukan kepada Bawaslu, bukan setiap lembaga punya kewenangan sendiri-sendiri. Termasuk kewenangan dalam menyelesaiakan sengketa melalui peradilan yang proses penyelesaian perkara pemilukada salah staunya memang hingga saat ini masih diselesaiakan di Mahkamah Konstitusi ${ }^{14}$.

Posisi Bawaslu dalam peraturan perundang-undangan di Indonesia yang terkesan sebagai lembaga Pendukung karena dibatasi wewenang lembaga lain menjadi cara berfikir yang harus ditinggalkan dalam menangani sengketa pemilu dan pilkada. Oleh Sani T. $\mathrm{P}^{15}$ dikatakan dalam pelaksanaan Sentra Gakkumdu diperlukan sebuah kesepakatan dan kerjasama yang baik untuk mencapai tujuan penindakan tindak pidana pemilu. Oleh karena itu diperlukannya kolaborasi antara ketiga lembaga anggota Sentra Gakkumdu untuk mewujudkan kerjasama yang baik. Namuan tetap dalam hal ini terdapat titik koordinat keputusan tentunya yaitu pada Bawaslu.

Gagasan demikian menjadi bentuk alternatif yang sangat tepat sesuai dengan ruh dibentuknya Sentra Gakkumdu yang independent dan tidak terkooptasi oleh lembaga asal yaitu kepolisian dan kejaksaan yang bersangkutan yang bersifat hierarkis, yang terlibat dalam Sentra Gakkumdu. Disini perlu upaya menempatkan Bawaslu sebagai kelembagaan yang final melakukan penentuan keputusan atas proses penyidikan dan penyelidikan sampai kepada proses penuntutan di pengadilan. Oleh Angelo Emanuel (2017) dengan istilah penguatan Bawaslu dalam hal penyederhanaan sistem penegakan hukum dan penyelesaian sengketa pemilu yaitu Bawaslu berwenang menegakkan pelanggaran administrasi pemilu, dan menjadi penyidik dan penuntut atas dugaan pelanggaran pidana pemilu yang berdampak langsung terhadap hasil pemilu.

14 Saragih, A. D. A. (2017). Tinjauan Yuridis Pentingnya Pembentukan Peradilan Khusus dalam PEMILU Serentak Menurut Undang-Undang Pemilihan Kepala Daerah. Jurnal Lex et Societatis, 5(3).

15 Sani, T. P. (2019). Peran Kejaksaan dalam Sentra Penegakan Hukum Terpadu (Gakkumdu) pada Pemilu 2019 (Studi Lapangan: Kejaksaan Negeri Tebing Tinggi). 
Upaya untuk mempertimbangkan posisi Bawaslu secara sentral adalah agar lembaga Bawaslu ditempatkan sebagai penentu pada proses penanganan awal (penyelidikan) mulai dari laporan atau temuan, klarifikasi, mengumpulkan alat bukti, dan lain-lain. Kemudian sifat rekomendasi yang wajib ditindaklanjuti dari Bawaslu kepada penyidik kepolilisian dan penuntut kejaksaan yang hal tersebut semata-mata bertujuan agar equal sesuai dengan kewenangan dan tanggung jawab masing-masing lembaga kepada Bawaslu dengan mempertimbangkan Bawaslu sebagai lembaga yang lebih memiliki kepasitas independensi dibandingkan lembaga lainnya.

Model penanganan yang demikian tentunya bertujuan untuk menghadirkan sistem penyelenggaran pilkada yang bermartabat dengan mengedepankan aspek kepastian hukum atas pelanggaran pilkada yang terjadi. Sinergi kelembagaan menjadi salah satu instrument penting dalam mengatasi masalah itu semua. Terlepas dari gagasan bawaslu sebagai pusat koordinasi dan keputusan pelanggaran pilkada melalui sentra gakkumdu, gagasan demikian dalam penyelesaian tindak pidana "money politics" diantaraya maka Sentra Gakkumduharus menjadi unsur kelembagaan yang bersifat koordinatif dalam melakukan penelitian dan pengkajian melalui mekanisme gelar perkara setiap laporan pelanggaran yang diterima dari bawaslu maupuan lembaga lain yang tergabung dalam sentra Gakkumdu. Sehingga dalam pelaksanaan tugas di Sentra Gakkumdutersebut wajib menerapkan prinsip koordinasi, integrasi dan sinkronisasi baik dalam pelaksanaan tugas yang bersifat internal maupun eksternal, sesuai dengan asas Integrated Criminal Justice System ${ }^{16}$.

Memposisikan kembali Bawaslu tentunya menjadi penting dalam membangun ketidak percayaan publik dari pemilu ke pemilu dikarenakan tidak konsistennya kontestan yang telah terpilih sebagai pemimpin untuk merealisasikan visi misinya di pemilukada lalu, sehingga membawa dampak timbulnya ketidak percayaan publik terhadap momen pemilukada. Sikap apatis warga kemudian

16 Mully, E., Dewi, E., \& Husin, B. R. (2018). Peran Penegak Hukum Terpadu Dalam Menanggulangi Tindak Pidana "Money Politics" Terhadap Sistem Pemilu Kepala Daerah. Poenale: Jurnal Bagian Hukum Pidana, 6(1). 
“dibeli” melalui pendekatan transaksional sehingga membengkakan keuangan para kontestan di pemilukada disamping juga besarnya keuangan yang dialokasikan pada pengadaan iklan politik atau alat peraga ${ }^{17}$. Dengan penguatan pidana pemilu melalui peran bawaslu secara sentral tentunya akan lebih efektif dalam penegakan pidana pemilu dan pilkada nantinya.

Ide tersebut tentunya perlu didukung secara yuridis, melalui remodifikasi beberapa peraturan perundang-undangan. Di sini peran partai politik sangatlah penting untuk mendukung. Maka partai politik perlu mempertimbangkan untuk melakukan dukungan atas kebijakan Sentra Gakkumdu demikian. Peran partai politik yang demikian sangatlah penting ikut serta menjaga kualitas pelaksaan pemilu dan pilkada dapat sesuai yang diharapkan. Hal ini pada sisi lain menjadi penting bagi partai politik mengingat bagaimana partai politik mempertahankan citra mereka di depan publik dan pada saat yang sama membentuk pola interaksi mereka dii pemerintahan dan parlemen ${ }^{18}$.

Hal ini sebagaimana pandangan Mukthie Fadjar ${ }^{19}$ menegaskan fungsi partai politik secara umum adalah : Sebagai sarana komunikasi politik, yaitu di satu pihak merumuskan kepentingan (interest articulation) dan menggabungkan atau menyalurkan kepentingan (interest aggregation) masyarakat untuk disampaikan dan diperjuangkan kepada pemerintah, sedangkan di pihak lain juga berfungsi menjelaskan dan menyebarluaskan kebijaksanaan pemerintah kepada masyarakat (khususnya anggota partai politik yang bersangkutan. Sudah saatnya memang pandangan kajian oleh Umanailo, M. C. B $^{20}$. dihilangkan, yang menyatakan bahwa partai politik bukan lagi menjadi sandaran ideologi konstituennya, yang selalu dekat dan merasa terdidik untuk terus mendapatkan pemahaman politiknya, namun saat

17 Sinaga, R. S. (2013). Implikasi Distorsi Demokrasi Pada Pemilukada terhadap Penguatan Demokrasi Lokal. Jurnal PERSPEKTIF, 2(1). http://dx.doi.org/10.31289/perspektif.v2i1.107

18 Aminuddin, M. F., \& Ramadlan, M. F. S. (2015). Match-All party: Pragmatisme Politik Dan Munculnya Spesies Baru Partai Politik Di Indonesia Pasca Pemilu 2009. Jurnal Politik, 1(1), 39-74. https://doi.org/10.7454/jp.v1i1.9

19 Sirajuddin dan Winardi, 2015, Opcit, hlm 282-283

20 Umanailo, M. C. B. (2017). Mereduksi Multi Partai Untuk Kestabilan Pembangunan Nasional. DOI: $10.31219 /$ osf.io/e $37 \mathrm{fp}$ 
ini, partai politik telah berubah menjadi gerombolan orang berpolitik untuk mendapatkan dan mempertahankan kekuasaan.

Fungsi partai politik yang demikian sangatlah satrategis dalam mewujudkan sistem penyelenggaran pemilu dan pilkada yang berkualitas pada masayang akan datang dengan melakukan reposisi kedudukan Sentra Gakkumdu dalam penyelesaikan tindak pidana pemilu dan pilkada. Peranan partai politik dilakukan baik dalam merubah undang-undang pilkada yang menekankan kewenangan Bawaslu dalam pelaksanaan pengawasan pilkada melalui Sentra Gakkumdu maupun peran partai politik dilakukan dengan menjalankan sikap dalam kontestasi pilkada maupun pemilu secara berintegritas di Negara Republik Indonesia.

\section{PENUTUP}

Tindak pidana pilkada yang selama ini terjadi secara terus menerus dan berkelanjutan dalam pelaksanaan pemilu mapun pilkada menjadi salah satu akumulasi dari model penanganan yang dilakukan oleh Sentra Gakkumdu tidak berjalan maksimal secara faktual. Beberapa upaya startegis yang perlu dilakukan dalam mewujudkan penyelenggaraan pilkada yang bermartabat diantaranya adalah dengan menempatkan sistem koordinasi dalam menjalankan kewenangan oleh elemen-element yang ada baik kepolisian, kejaksaan, dan bawaslu, akan tetapi bersifat tidak sejajar antara lembaga tersebut. Kedudukan dalam memutus akhir tetap harus ada di lembaga Bawaslu, hal tersebut mengingat Bawaslu dapat dinilai lebih independen dari pada penegak hukum yang lain dalam penanganan pidana pemilu. Pada sisi lain melalui upaya tersebut diharapkan agar menjaga kualitas pilkada dilaksanakan secara bermartabat dan konstitusional. Namun tentunya, konsep demikian dapat memiliki legalitas apabila ditetapkan melalui subtansi nyata yang terdapat peraturan perundang-undangan yang selama ini mengatur perihal posisi Sentra Gakkumdu sebagai norma teknis dalam pelaksaaan pemilu dan pilkada melalui dukungan dan sikap partai politik yang memiliki kelembagan di Dewan Perwakilan Rakyat Republik Indonesia. 


\section{DAFTAR PUSTAKA}

\section{Buku}

Baum, L. (2003). Judicial Elections And Judicial Independence: The Voter's Perspective. Ohio St. LJ.

Berdejó, C., \& Yuchtman, N. (2013). Crime, Punishment, And Politics: An Analysis Of Political Cycles In Criminal Sentencing. Review Of Economics And Statistics.

Lexi J. Moleong, Metodologi Penelitian Kualitatif, Bandung : PT Remaja Rosdakarya, 2018.

Ni'matul Huda, 2015, Hukum Tata Negara Indonesia, Raja Grafindo Persada, Jakarta.

Sirajuddin dan Winardi, 2015, Hukum Tata Negara Indonesia, Setara Press(Kelompok Instras Publising), Malang.

Zainal Asikin, 2013, Pengantar Tata Hukum Indonesia, Raja Grafindo Persada, Jakarta.

\section{Jurnal}

Aminuddin, M. F., \& Ramadlan, M. F. S. (2015). Match-All Party: Pragmatisme Politik Dan Munculnya Spesies Baru Partai Politik Di Indonesia Pasca Pemilu 2009. Jurnal Politik, 1(1).

https://doi.org/10.7454/jp.v1i1.9

Ersan, P., \& Erliyana, A. (2018). Kualifikasi Hukum Pidana Khusus Terhadap Tindak Pidana Pemilu/Pilkada (Tinjauan Hukum Administrasi Negara). Pakuan Law Review, 4(1). https://doi.org/10.33751/palar.v4i1

Fahmi, Khairul. (2015). Sistem Penanganan Tindak Pidana Pemilu, Jurnal Konstitusi, 12(2). http://dx.doi.org/10.31078/jk1224

Handitya, B. (2018). Peran Sentra Penegakan Hukum Terpadu (Gakkumdu) dalam Penegakkan Tindak Pidana Pemilu. In Seminar Nasional Hukum Universitas Negeri Semarang (Vol. 4, No. 02).

Mully, E., Dewi, E., \& Husin, B. R. (2018). Peran Penegak Hukum Terpadu Dalam Menanggulangi Tindak Pidana "Money Politics" Terhadap Sistem Pemilu Kepala Daerah. Poenale: Jurnal Bagian Hukum Pidana, 6(1).

Perbawa, S. L. P. (2019). Penegakan Hukum Dalam Pemilihan Umum. Jurnal Ilmiah Dinamika Sosial, 3(1), 80-102.

https://doi.org/10.38043/jids.v3i1.1765

Safitri, E. F. (2019). Analisis Peran Sentra Penegakan Hukum Terpadu (Gakkumdu) Dalam Penanggulangan Tindak Pidana Pemilihan Kepala Daerah (Studi Pada Provinsi Lampung).

Sani, T. P. (2019). Peran Kejaksaan dalam Sentra Penegakan Hukum Terpadu (Gakkumdu) pada Pemilu 2019 (Studi Lapangan: Kejaksaan Negeri Tebing Tinggi).

Saragih, A. D. A. (2017). Tinjauan Yuridis Pentingnya Pembentukan Peradilan Khusus dalam PEMILU Serentak Menurut Undang-Undang Pemilihan Kepala Daerah. Jurnal Lex et Societatis, 5(3). 
Sinaga, R. S. (2013). Implikasi Distorsi Demokrasi Pada Pemilukada terhadap Penguatan Demokrasi Lokal. Jurnal PERSPEKTIF, 2(1). http://dx.doi.org/10.31289/perspektif.v2i1.107

Solihah, R., \& Witianti, S. (2017). Permasalahan dan Upaya Mewujudkan Pemilu Demokratis di Indonesia Pasca Reformasill. Jurnal Bawaslu, 3(1).

Umanailo, M. C. B. (2017). Mereduksi Multi Partai Untuk Kestabilan Pembangunan Nasional. DOI: 10.31219/osf.io/e37fp

Yeni, Y. (2020). Peran Sentra Penegakan Hukum Terpadu (Gakkumdu) Dalam Penindakan Tindak Pidana Pemilu Pada Pemilihan Anggota Dewan Perwakilan Rakyat Daerah Kabupaten Solok Tahun 2019. Abstract of Undergraduate Research, Faculty of Law, Bung Hatta University, 11(1). 